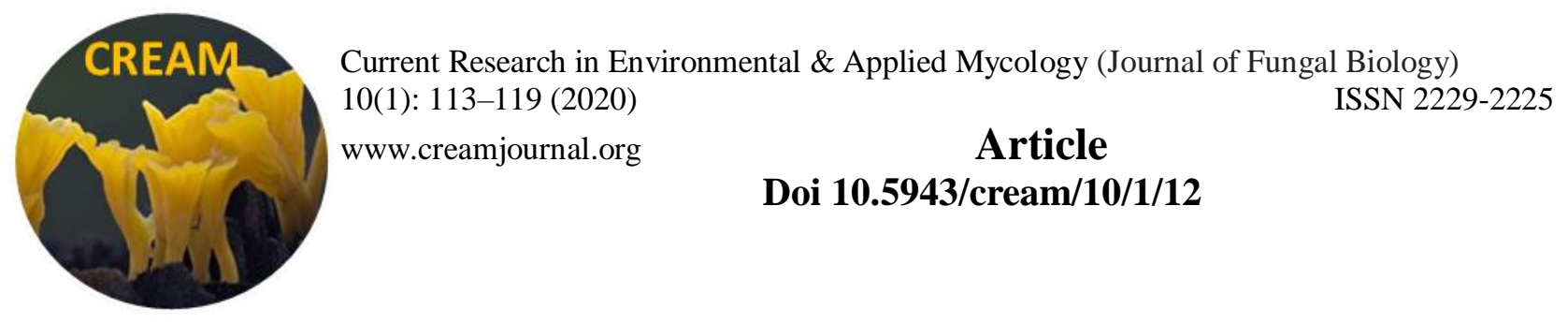

\title{
Revealing new active and biotechnologically perspective producers of oxidative and cellulolytic enzymes among pure cultures of xylotrophic Agaricomycetes from the Southern Non-Chernozem zone of the European part of Russia
}

\author{
Shakhova $\mathrm{NV}^{1 *}$ and Volobuev $\mathrm{SV}^{2}$ \\ 1 Laboratory of Biochemistry of Fungi, Komarov Botanical Institute of the Russian Academy of Sciences, \\ St. Petersburg, Russia \\ ${ }^{2}$ Laboratory of Systematics and Geography of Fungi, Komarov Botanical Institute of the Russian Academy of Sciences, \\ St. Petersburg, Russia
}

Shakhova NV, Volobuev SV 2020 - Revealing new active and biotechnologically perspective producers of oxidative and cellulolytic enzymes among pure cultures of xylotrophic Agaricomycetes from the Southern Non-Chernozem zone of the European part of Russia. Current Research in Environmental \& Applied Mycology (Journal of Fungal Biology) 10(1), 113-119, Doi $10.5943 /$ cream/10/1/12

\begin{abstract}
A total of 60 fungal strains from 33 species of xylotrophic macrofungi (Agaricomycetes, Basidiomycota) inhabiting on the territory of the State Natural Biosphere Reserve "Bryanskiy les" (Bryansk Oblast, European Russia) were analyzed by the method of rapid screening in order to determine the lignocellulolytic enzymes. As a result of the qualitative analysis, a group of fungi with the highest lignocellulolytic and degradation potential, including representatives of the families Fomitopsidaceae, Meruliaceae, Polyporaceae and Steccherinaceae (Polyporales), was revealed. For the first time Rhodofomes roseus was shown to be able to decolorize polyphenolic dye azure B. Strains of LE-BIN 3969 Rhodofomes roseus, LE-BIN 4122 Trametes hirsuta and LEBIN 4123 Trametes ochracea, which are of high interest for quantitative analysis of their enzymatic potential and use in biotechnology, were selected.
\end{abstract}

Key words - cellulases - discoloration - fungal biotechnology - ligninases - wood-inhabiting basidiomycetes

\section{Introduction}

Celluloses, hemicelluloses and lignin are the main components that make up the base of woody plant cell walls. Lignin protects cellulose and hemicellulose and is highly resistant to degradation due to its aromatic nature and structural heterogeneity. Due to this feature, lignocellulose components of wood are the most resistant to chemical and microbiological destruction by biopolymers. Agaricomycetes are an integral part of any forest ecosystem and play a crucial role in carbon balance, soil formation and reforestation, as they have a unique ability to destroy all components of the plant cell wall, including lignin (Floudas et al. 2012, Barrasa et al. 2014). 
Basidial fungi produce a variety of extracellular enzymes involved in the process of modification and destruction of lignin. Currently, the common name of these enzymes is ligninases, which can be divided into 2 groups: phenoloxidases - laccases (EC 1.10.3.2) and gem-containing peroxidases, namely lignin peroxidase (E C 1.11.1.14), manganese peroxidase (EC 1.11.1.13) and polyfunctional peroxidase (EC 1.11.1.16) (Wong 2009, Manavalan et al. 2014). Cellulose hydrolysis with basidial fungi is carried out by a complex of enzymes - cellulases. At least three types of enzymes with cellulolytic activity are known: exo- $\beta-1,4-$ glucanase (EC 3.2.1), endo- $\beta-1$, 4-glucanase (EC 3.2.1.4), and $\beta$-glucosidase (EC 3.2.1.21) (Manavalan et al. 2014). In addition, due to the unique set of the lignocellulolytic complex enzymes, this group of fungi is attractive in various areas of biotechnology: detoxification and delignification of industrial waste, bleaching of wastewater and paper pulp, fine organic synthesis and biosensor technology (Klein et al. 2011, Upadhyay et al. 2016, Costa et al. 2017). Therefore, work is constantly carried out to find, isolate and study new strains of basidiomycetes, promising for use in a wide range of applied aspects.

The aim of this work was to screen wood-inhabiting macromycetes under conditions of solidphase cultivation in order to discover strains with high lignolytic, cellulolytic and detoxifying potential, which are prospective for use in biotechnology.

\section{Materials \& Methods}

\section{Isolation and verification of fungal strain cultures}

In this work we studied 60 pure cultures of 33 species of xylotrophic basidiomycetes (Agaricomycetes, Basidiomycota) obtained in 2015-2018 in the territory of the "Bryanskiy les"

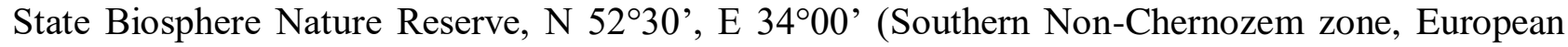
Russia) from specimens of different substrate (host tree) origin (Table 1).

Ex situ isolation of basidiomycetes was carried out by traditional methods of solid-phase culturing: by seeding of basidiospores or by placing small fragments of basidiocarps on an agarized substrate (4\% ale-wort "Severnaya Pivovarnya", pH 5.8 and 2\% agar "Difco"), with the addition of kanamycin water solution (final concentration in the medium $-0.5 \mathrm{mg} / \mathrm{ml}$ ) in order to prevent bacterial contamination. Identification of fungi, as well as macro- and micromorphological features of isolates were characterized by cultural and morphological parameters using the method and terminology of Stalpers (1978). Strains were deposited in the Komarov Botanical Institute Basidiomycetes Culture Collection (LE-BIN) (St. Petersburg, Russia) and are stored using the subculture method, the disk method and the cryopreservation method (Psurtseva 2018).

\section{Growth measurement}

To characterize the linear growth rate (LGR), cultures of basidial fungi were grown in Petri dishes with a diameter of $90 \mathrm{~mm}$ on standard Malt Extract Agar (MEA, "Conda") in the dark at $25^{\circ} \mathrm{C}$. Cultivation of strains was carried out with mycelial blocks (diameter $\mathrm{d}, 7 \mathrm{~mm}$ ) from the edge zone of the actively growing colony, placing them on the nutrient medium close to the edge of Petri dishes with the mycelial layer down. The growth of strains was characterized by the radius of the colony by 7, 14, 21 and 28 days, estimating the growth rate by the rate of cup overgrowth: fast growth $(\mathrm{F})-1$ week, medium $(\mathrm{M})-2-3$ weeks and slow $(\mathrm{S})-4$ weeks or more.

\section{Detection of enzymatic activity}

The activity of lignolytic and cellulolytic enzymatic complexes was studied using the rapid screening method. The strains were grown on a MEA medium in a thermostat at $25^{\circ} \mathrm{C}$ for 2 weeks. Cultivation of strains was carried out with mycelial blocks d $7 \mathrm{~mm}$ from the edge zone of the actively growing colony, placing them in the center of the Petri dish with a micellar layer upwards.

The qualitative activity of oxidative enzymes in the studied fungi was determined by the method of application (Pointing 1999), based on the ability of strains-producers to oxidize the ABTS substrate. The activity of oxidoreductases was registered 48 hours after placing the mycelial blocks of the studied fungi on MEA, containing ABTS (in concentration of $0.1 \%$ ) by the presence 
of violet staining around the inoculants $(\mathrm{d}, \mathrm{mm})$. The following criteria were used to assess the intensity of the substrate oxidation reaction: the colored zone is less than $10 \mathrm{~mm}$ - slightly positive reaction; zone 11-20 $\mathrm{mm}$ - positive reaction; zone more than $25 \mathrm{~mm}$ - strongly positive reaction (Fig. 2A).

The qualitative activity of cellulolytic enzymes in cultures was determined using microcrystalline cellulose (1.0\% CMC and 1.0\% agar "Difco") by the application method and estimated by the presence of a clear zone around inoculum $(\mathrm{d}, \mathrm{mm})$. The enlightened zone was detected 48 hours after inoculation using solution I in KI $(0.5 \%$ I in $2 \% \mathrm{KI})$ (Klán \& Baudišová 1990). The same parameters were used to estimate the intensity of the reaction as in determining the activity of oxidoreductases (Fig. 2B).

\section{Dye decolorization assays in agar plates}

The test for decoloration of polyphenolic dye azure $\mathrm{B}$, indicating the presence of ligninperoxidase and $\mathrm{H}_{2} \mathrm{O}_{2}$-producing oxidase in basidiomycetes, was carried out on Petri dishes (diameter $90 \mathrm{~mm}$ ). Cultivation media for this analysis included MEA containing $75 \mathrm{mg} / 1$ polyphenolic dye azure B ("Sigma") (Barrasa et al. 2014). Cultivation of strains (grown on standard MEA nutrient media) was carried out with $\mathrm{d} 7 \mathrm{~mm}$ mycelial blocks from the edge zone of the actively growing colony, placing them in the center of the Petri dish (with dye) with the mycelial layer downwards. The strains were incubated in a thermostat at $25^{\circ} \mathrm{C}$ for 14 days (Fig. $2 \mathrm{C}, \mathrm{D}$ ). Mycelium growth and dye bleaching were characterized by the colony diameter/bleaching of azure B (mm), measuring them after 7 and 14 days of cultivation.

Cultivation in all experiments was performed in at least three repetitions. Microsoft Excel and OriginPro 7.5 software were used for statistical data processing.

\section{Results}

Strains of all the species involved in the experiment demonstrated the activity of both individual enzymes and multienzyme complexes (Table 1). It was determined that the absolute majority of strains $(95.2 \%)$ included in the study were found to be positive in relation to cellulolytic enzymes (57 strains), while $36.2 \%$ of strains demonstrated high enzymatic potential (Fig. 1). Over $3 / 4$ of all strains (76.9\%) showed ABTS oxidation ability as a result of oxidoreductases (46 strains), of which $36.8 \%$ had high lignolytic activity. Sixty one percent of the strains under consideration were characterized by the ability to discolor polyphenolic dye azure $\mathrm{B}$, while $31.6 \%$ showed high detoxification potential (Fig. 1).

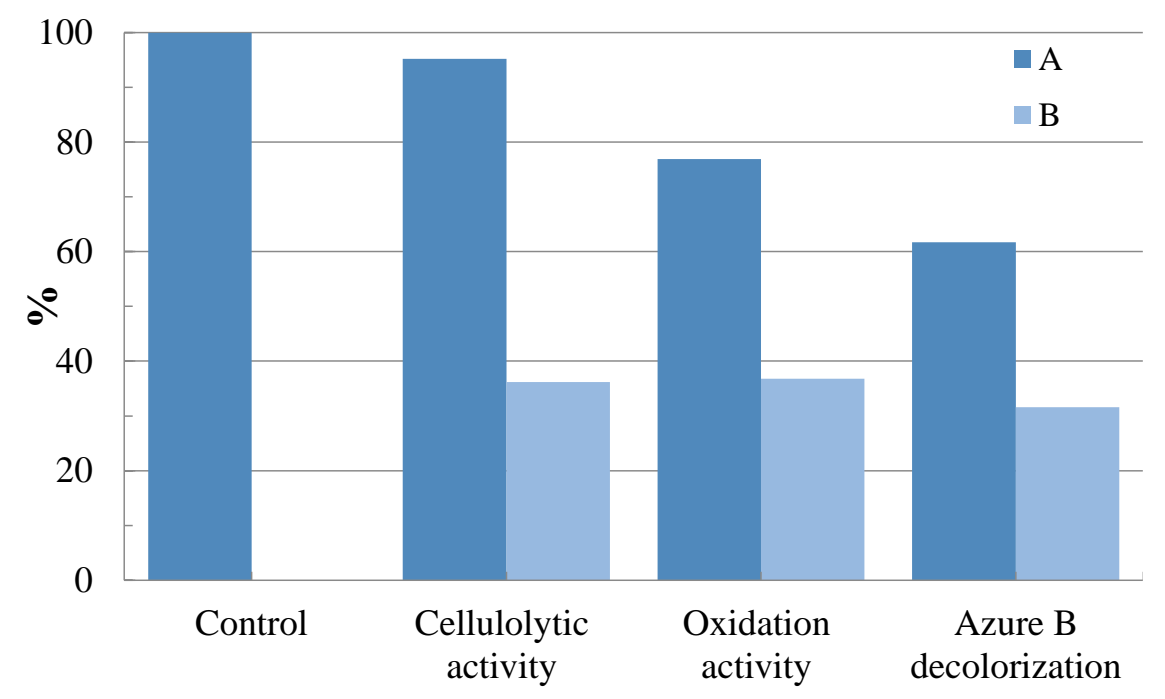

Fig. 1 - Ratio of the studied fungal strains by oxidative and cellulolytic activities and degradation potential: A Strains with positive reaction to enzymatic/degradation activity. B Strains with high enzymatic/detoxifying potential. 
Table 1 Results of the express assays of oxidative and cellulolytic enzymes and detoxification potential in pure cultures of basidiomycetes.

\begin{tabular}{|c|c|c|c|c|c|c|c|}
\hline \multirow[t]{2}{*}{ Species } & \multirow{2}{*}{$\begin{array}{l}\text { Strains } \\
\text { numbers } \\
\text { (LE-BIN) }\end{array}$} & \multirow{2}{*}{$\begin{array}{l}\text { Substrate } \\
\text { (host tree) }\end{array}$} & \multirow[t]{2}{*}{ LGR } & \multicolumn{2}{|c|}{$\begin{array}{l}\text { Enzymatic activity, } \\
\text { d (mm) }\end{array}$} & \multicolumn{2}{|c|}{$\begin{array}{l}\text { Azure B } \\
\text { decolorization }\end{array}$} \\
\hline & & & & ABTS & CMC & 7-day & 14-day \\
\hline \multicolumn{8}{|c|}{ AGARICALES } \\
\hline \multicolumn{8}{|c|}{ Pleurotaceae } \\
\hline \multirow{2}{*}{ Pleurotus ostreatus } & 4126 & ACEpla & M & $17.9 \pm 1.0$ & $21.2 \pm 1.0$ & $\mathrm{n} / \mathrm{d}$ & $\mathrm{n} / \mathrm{d}$ \\
\hline & 4132 & ACEpla & M & $15.7 \pm 0.7$ & $21.4 \pm 0.9$ & $\mathrm{n} / \mathrm{d}$ & $\mathrm{n} / \mathrm{d}$ \\
\hline Pleurotus pulmonarius & 4111 & POPtre & M & $18.6 \pm 1.2$ & $28.8 \pm 1.1$ & $\mathrm{n} / \mathrm{d}$ & $\mathrm{n} / \mathrm{d}$ \\
\hline \multicolumn{8}{|c|}{ Pterulaceae } \\
\hline Radulomyces confluens & 3587 & POPtre & $\mathrm{F}$ & $10.4 \pm 0.6$ & $20.7 \pm 0.6$ & $\mathrm{n} / \mathrm{d}$ & $\mathrm{n} / \mathrm{d}$ \\
\hline \multicolumn{8}{|c|}{ CANTHARELLALES } \\
\hline \multicolumn{8}{|c|}{ Hydnaceae } \\
\hline Sistotrema raduloides & 3583 & POPtre & $\mathrm{S}$ & $\mathrm{n} / \mathrm{d}$ & $25.5 \pm 0.6$ & $\mathrm{n} / \mathrm{d}$ & $23.1 \pm 1.1$ \\
\hline \multicolumn{8}{|c|}{ CORTICIALES } \\
\hline \multirow{2}{*}{\multicolumn{8}{|c|}{ НYMENOCHAETALES }} \\
\hline & & & & & & & \\
\hline \multicolumn{8}{|c|}{ Hymenochaetaceae } \\
\hline Inocutis rheades & 4112 & POPtre & M & $21.6 \pm 1.0$ & $\mathrm{n} / \mathrm{d}$ & $\mathrm{n} / \mathrm{d}$ & $63.7 \pm 2.3$ \\
\hline Phellinus laevigatus & 4108 & BETpen & $\mathrm{F}$ & $19.8 \pm 3.0$ & $18.2 \pm 1.1$ & $14.7 \pm 0.8$ & $52.3 \pm 1.6$ \\
\hline \multicolumn{8}{|c|}{ Schizoporaceae } \\
\hline & 3967 & POPtre & $\mathrm{F}$ & $26.2 \pm 0.9$ & $19.8 \pm 1.4$ & $\mathrm{n} / \mathrm{d}$ & $\mathrm{n} / \mathrm{d}$ \\
\hline Xylodon paradoxus & 3973 & POPtre & $\mathrm{F}$ & $28.1 \pm 1.2$ & $20.2 \pm 1.1$ & $\mathrm{n} / \mathrm{d}$ & $\mathrm{n} / \mathrm{d}$ \\
\hline \multicolumn{8}{|c|}{ POLYPORALES } \\
\hline \multicolumn{8}{|c|}{ Cerrenaceae } \\
\hline Spongipellis spumea & 3598 & POPtre & $\mathrm{F}$ & $\mathrm{n} / \mathrm{d}$ & $25.3 \pm 1.1$ & $\mathrm{n} / \mathrm{d}$ & $56.3 \pm 1.4$ \\
\hline & & & itopsida & eae & & & \\
\hline & 4109 & BETpen & $\mathrm{F}$ & $\mathrm{n} / \mathrm{d}$ & $23.6 \pm 0.9$ & $\mathrm{n} / \mathrm{d}$ & $\geq 85.0$ \\
\hline Fomitopsis betulına & 4115 & BETpen & $\mathrm{F}$ & $\mathrm{n} / \mathrm{d}$ & $21.7 \pm 1.3$ & $\mathrm{n} / \mathrm{d}$ & $\geq 85.0$ \\
\hline Rhodofomes roseus & 3969 & POPtre & M & $29.4 \pm 1.0$ & $22.7 \pm 1.2$ & $35.5 \pm 0.1$ & $82.0 \pm 1.4$ \\
\hline & & $H y$ & dermat & ceae & & & \\
\hline & 3596 & POPtre & M & $14.8 \pm 0.8$ & $25.6 \pm 0.6$ & $\mathrm{n} / \mathrm{d}$ & $14.8 \pm 1.0$ \\
\hline Hурhоderma mutatum & 3974 & POPtre & M & $25.5 \pm 1.5$ & $22.3 \pm 0.9$ & $\mathrm{n} / \mathrm{d}$ & $14.3 \pm 0.8$ \\
\hline & & & stoporia & eae & & & \\
\hline $\begin{array}{l}\text { Skeletocutis } \\
\text { semipileata }\end{array}$ & 4124 & CORave & M & $25.7 \pm 1.5$ & $30.0 \pm 0.8$ & $\mathrm{n} / \mathrm{d}$ & $12.2 \pm 0.8$ \\
\hline Tyromyces chioneus & 3990 & ALNglu & $\mathrm{S}$ & $\mathrm{n} / \mathrm{d}$ & $42.7 \pm 1.3$ & $44.6 \pm 2.2$ & $\geq 85.0$ \\
\hline & & & picacea & & & & \\
\hline Gloeoporus dichrous & 3978 & CORave & M & $\mathrm{n} / \mathrm{d}$ & $10.4 \pm 0.9$ & $21.1 \pm 0.4$ & $70.3 \pm 2.1$ \\
\hline & 4110 & CORave & M & $\mathrm{n} / \mathrm{d}$ & $19.7 \pm 1.1$ & $20.8 \pm 0.8$ & $72.2 \pm 1.7$ \\
\hline Trametopsis cervina & 3607 & POPtre & $\mathrm{F}$ & $10.3 \pm 0.7$ & $27.6 \pm 1.4$ & $40.5 \pm 0.6$ & $\geq 85.0$ \\
\hline & & & ifomita & & & & \\
\hline Rhodonia placenta & 3992 & PINsyl & $\mathrm{F}$ & $24.9 \pm 0.7$ & $19.8 \pm 1.4$ & $\mathrm{n} / \mathrm{d}$ & $\mathrm{n} / \mathrm{d}$ \\
\hline & & & eruliace & & & & \\
\hline Aurantiporus fissilis & 4002 & POPtre & $\mathrm{F}$ & $\mathrm{n} / \mathrm{d}$ & $33.4 \pm 1.0$ & $22.3 \pm 0.8$ & $36.4 \pm 1.6$ \\
\hline & 4119 & ACEpla & M & $26.0 \pm 1.2$ & $21.8 \pm 0.9$ & $\geq 85.0$ & $\geq 85.0$ \\
\hline Phlebia rufa & 4127 & POPtre & M & $20.9 \pm 1.9$ & $\mathrm{n} / \mathrm{d}$ & $74.2 \pm 3.4$ & $79.7 \pm 1.9$ \\
\hline & 4128 & ACEpla & M & $20.2 \pm 2.1$ & $26.1 \pm 0.9$ & $77.0 \pm 2.5$ & $\geq 85.0$ \\
\hline Phlebia tremellosa & 3591 & TILcor & $\mathrm{F}$ & $18.4 \pm 0.6$ & $20.9 \pm 0.7$ & $\mathrm{n} / \mathrm{d}$ & $\mathrm{n} / \mathrm{d}$ \\
\hline & & $P h c$ & rochaet & ceae & & & \\
\hline Bjerkandera adusta & 3996 & POPtre & $\mathrm{F}$ & $\mathrm{n} / \mathrm{d}$ & $25.7 \pm 1.0$ & $38.5 \pm 0.8$ & $\geq 85.0$ \\
\hline Bjerkandera fumosa & 4107 & ALNglu & $\mathrm{F}$ & $\mathrm{n} / \mathrm{d}$ & $24.8 \pm 0.8$ & $63.7 \pm 2.3$ & $82.3 \pm 2.1$ \\
\hline & & & yporace & & & & \\
\hline $\begin{array}{l}\text { Daedaleopsis } \\
\text { confragosa }\end{array}$ & 3989 & POPtre & M & $18.3 \pm 0.8$ & $24.9 \pm 0.8$ & $\mathrm{n} / \mathrm{d}$ & $24.5 \pm 1.0$ \\
\hline Ganoderma & 3582 & POPtre & $\mathrm{F}$ & $17.4 \pm 2.0$ & $22.8 \pm 0.8$ & $\mathrm{n} / \mathrm{d}$ & $\mathrm{n} / \mathrm{d}$ \\
\hline applanatum & 4003 & QUErob & $\mathrm{F}$ & $\mathrm{n} / \mathrm{d}$ & $22.2 \pm 0.8$ & $\mathrm{n} / \mathrm{d}$ & $\mathrm{n} / \mathrm{d}$ \\
\hline Trametes hirsuta & 4122 & ACEpla & $\mathrm{F}$ & $26.9 \pm 0.9$ & $31.6 \pm 1.0$ & $26.5 \pm 1.4$ & $31.0 \pm 2.3$ \\
\hline
\end{tabular}


Table 1 Continued.

\begin{tabular}{|c|c|c|c|c|c|c|c|}
\hline \multirow[t]{2}{*}{ Species } & \multirow{2}{*}{$\begin{array}{l}\text { Strains } \\
\text { numbers } \\
\text { (LE-BIN) }\end{array}$} & \multirow{2}{*}{$\begin{array}{l}\text { Substrate } \\
\text { (host tree) }\end{array}$} & \multirow[t]{2}{*}{ LGR } & \multicolumn{2}{|c|}{$\begin{array}{l}\text { Enzymatic activity, } \\
\text { d (mm) }\end{array}$} & \multicolumn{2}{|c|}{$\begin{array}{l}\text { Azure B } \\
\text { decolorization }\end{array}$} \\
\hline & & & & ABTS & CMC & 7-day & 14-day \\
\hline Trametes gibbosa & 3578 & QUErob & $\mathrm{F}$ & $14.9 \pm 0.7$ & $23.7 \pm 0.9$ & $\mathrm{n} / \mathrm{d}$ & $73.2 \pm 1.0$ \\
\hline Trametes ochracea & 4123 & ACEpla & $\mathrm{F}$ & $24.1 \pm 1.0$ & $31.1 \pm 0.9$ & $49.3 \pm 3.2$ & $\geq 85.0$ \\
\hline Trametes pubescens & 3995 & BETpen & $\mathrm{F}$ & $13.6 \pm 1.0$ & $\mathrm{n} / \mathrm{d}$ & $37.2 \pm 1.0$ & $62.7 \pm 1.6$ \\
\hline Pycnoporellus fulgens & 4114 & PICabi & $\begin{array}{l}\text { assidac } \\
\mathrm{M} \\
\text { cherinac }\end{array}$ & $\begin{array}{l}a e \\
\mathrm{n} / \mathrm{d} \\
a e\end{array}$ & $19.4 \pm 0.7$ & $19.2 \pm 0.8$ & $56.2 \pm 2.8$ \\
\hline \multirow{9}{*}{ Metuloidea fragrans } & 3576 & CORave & $\mathrm{S}$ & $25.6 \pm 1.4$ & $15.9 \pm 0.7$ & $\mathrm{n} / \mathrm{d}$ & $23.8 \pm 1.2$ \\
\hline & 3972 & CORave & M & $25.3 \pm 2.6$ & $24.6 \pm 1.9$ & $\mathrm{n} / \mathrm{d}$ & $\mathrm{n} / \mathrm{d}$ \\
\hline & 3976 & BETpen & M & $23.1 \pm 0.9$ & $23.0 \pm 0.5$ & $\mathrm{n} / \mathrm{d}$ & $\mathrm{n} / \mathrm{d}$ \\
\hline & 3980 & POPtre & M & $27.0 \pm 1.1$ & $25.5 \pm 0.8$ & $\mathrm{n} / \mathrm{d}$ & $\mathrm{n} / \mathrm{d}$ \\
\hline & 3982 & CORave & M & $19.7 \pm 1.6$ & $27.6 \pm 1.2$ & $\mathrm{n} / \mathrm{d}$ & $\mathrm{n} / \mathrm{d}$ \\
\hline & 3983 & CORave & M & $15.7 \pm 0.9$ & $24.6 \pm 1.0$ & $\mathrm{n} / \mathrm{d}$ & $\mathrm{n} / \mathrm{d}$ \\
\hline & 3991 & CORave & $S$ & $26.4 \pm 1.3$ & $22.9 \pm 1.0$ & $\mathrm{n} / \mathrm{d}$ & $24.5 \pm 0.8$ \\
\hline & 4000 & BETpen & S & $25.3 \pm 1.1$ & $22.8 \pm 1.2$ & $\mathrm{n} / \mathrm{d}$ & $28.7 \pm 1.8$ \\
\hline & 4001 & CORave & M & $30.3 \pm 1.8$ & $25.4 \pm 1.3$ & $\mathrm{n} / \mathrm{d}$ & $32.8 \pm 1.5$ \\
\hline \multirow{6}{*}{$\begin{array}{l}\text { Steccherinum } \\
\text { ochraceum }\end{array}$} & 3977 & CORave & M & $32.2 \pm 0.8$ & $30.3 \pm 1.2$ & $\mathrm{n} / \mathrm{d}$ & $\mathrm{n} / \mathrm{d}$ \\
\hline & 3981 & CORave & S & $32.5 \pm 0.7$ & $20.3 \pm 0.8$ & $\mathrm{n} / \mathrm{d}$ & $\mathrm{n} / \mathrm{d}$ \\
\hline & 3984 & CORave & $\mathrm{F}$ & $30.4 \pm 0.9$ & $29.4 \pm 1.4$ & $\mathrm{n} / \mathrm{d}$ & $13.4 \pm 0.4$ \\
\hline & 3985 & QUErob & $\mathrm{S}$ & $16.7 \pm 0.9$ & $20.9 \pm 1.2$ & $\mathrm{n} / \mathrm{d}$ & $14.9 \pm 0.2$ \\
\hline & 4005 & CORave & S & $33.1 \pm 1.2$ & $28.2 \pm 1.7$ & $\mathrm{n} / \mathrm{d}$ & $\mathrm{n} / \mathrm{d}$ \\
\hline & 3577 & CORave & $\mathrm{S}$ & $26.6 \pm 1.2$ & $13.5 \pm 0.5$ & $\mathrm{n} / \mathrm{d}$ & $\mathrm{n} / \mathrm{d}$ \\
\hline \multicolumn{8}{|c|}{ RUSSULALES } \\
\hline \multicolumn{8}{|c|}{ Hericiaceae } \\
\hline Hericium coralloides & 3594 & POPtre & $\mathrm{S}$ & $18.5 \pm 1.2$ & $12.1 \pm 0.6$ & $\mathrm{n} / \mathrm{d}$ & $\mathrm{n} / \mathrm{d}$ \\
\hline \multicolumn{8}{|c|}{ Stereaceae } \\
\hline Yvlobolus fructulatus & 3593 & QUErob & $\mathrm{S}$ & $\mathrm{n} / \mathrm{a}$ & $22.2 \pm 0.6$ & $\mathrm{n} / \mathrm{d}$ & $\mathrm{n} / \mathrm{d}$ \\
\hline Xylobolus frustulatus & 4125 & QUErob & M & $\mathrm{n} / \mathrm{a}$ & $21.6 \pm 0.6$ & $\mathrm{n} / \mathrm{d}$ & $\mathrm{n} / \mathrm{d}$ \\
\hline
\end{tabular}

* Abbreviations: $\mathrm{n} / \mathrm{d}$ - not detected, ACEpla - Acer platanoides, ALNglu - Alnus glutinosa, BETpen - Betula pendula, CORave - Corylus avellana, PICabi - Picea abies, PINsyl - Pinus sylvestris, POPtre - Populus tremula, QUErob Quercus robur, TILcor - Tilia cordata.

Screening revealed that the group of fungi with fast growth rate (1 week), the largest lignolytic and cellulolytic potential and sufficiently high ability to bleach polyphenolic dye azure B, includes representatives of the families Fomitopsidaceae (LE-BIN 3969 Rhodofomes roseus) and Polyporaceae (LE-BIN 4122 Trametes hirsuta, LE-BIN 4123 Trametes ochracea) (Table 1) that actively decompose wood in both boreal and temperate forest ecosystems.

\section{Discussion}

Discoloration of polyphenolic dyes with basidiomycetes may indicate not only the presence of lignin peroxidases and $\mathrm{H}_{2} \mathrm{O}_{2}$-producing oxidases. Hernández-Luna et al. (2008) show that some representatives of aphyllophoroid xylotrophic fungi have a correlation of ability to bleach polyphenolic dyes and degrade various xenobiotics (Hernández-Luna et al. 2008). Thus, the Azure B bleaching test can also be indirectly used as an evidence of high detoxification potential in this group of fungi.

Representatives of Meruliaceae (LE-BIN 4119 and 4128 Phlebia rufa) and Steccherinaceae (LE-BIN 4001 Metuloidea fragrans) families also showed high activity of lignocellulolytic enzymes and detoxification potential (Fig. 2). At the same time, LE-BIN 4001 Metuloidea fragrans was the only strain that combined active oxidative and cellulolytic enzymes with the ability to decolorize polyphenolic dye azure B. Other strains of this species showed active work of ligninases and cellulases but revealed a weakly positive reaction to the discoloration of azure B.

Strains of the species Steccherinum ochraceum (LE-BIN 3577, 3977, 3981, 3984, 3985 and 4005), showed similar screening results to those for Metuloidea fragrans, also belonging to the 
Steccherinaceae family.

In addition to the above strains, the results of a rapid test for the presence of oxidative enzymes revealed in representatives of the families Hyphodermataceae (LE-BIN 3974 Hyphoderma mutatum), Incrustoporiaceae (LE-BIN 4124 Skeletocutis semipileata), Laricifomitaceae (LE-BIN 3992 Rhodonia placenta), and Schizoporaceae (LE-BIN 3973 Xylodon paradoxus) have a high oxidation capacity of ABTS.

The greatest activity of cellulolytic enzymes was shown by strains belonging to families: Cerrenaceae (LE-BIN 3598 Spongipellis spumea), Hydnaceae (LE-BIN 3583 Sistotrema raduloides), Hyphodermataceae (LE-BIN 3596 Hyphoderma mutatum), Incrustoporiaceae (LEBIN 4124 Skeletocutis semipileata, LE-BIN 3990 Tyromyces chioneus), Irpicaceae (LE-BIN 3607 Trametopsis cervina), Meruliaceae (LE-BIN 4002 Aurantiporus fissilis), Phanerochaetaceae (LEBIN 3996 Bjerkandera adusta, LE-BIN 4107 Bjerkandera fumosa), Pleurotaceae (LE-BIN 4111 Pleurotus pulmonarius), Polyporaceae (LE-BIN 3989 Daedaleopsis confragosa). It is necessary to pay attention to the fact that six strains of fungi from the order of Polyporales (LE-BIN 4002 Aurantiporus fissilis, LE-BIN 3996 Bjerkandera adusta, LE-BIN 4107 Bjerkandera fumosa, LEBIN 3598 Spongipellis spumea, LE-BIN 3607 Trametopsis cervina, LE-BIN 3990 Tyromyces chioneus), which detected strongly active enzymes of the cellulolytic complex, also demonstrated a high detoxification potential.

The remarkable ability to decolorize polyphenolic dye azure B, along with the abovementioned strains, was also revealed for representatives of the family Hymenochaetaceae (LE-BIN 4112 Inocutis rheades and LE-BIN 4108 Phellinus laevigatus) from the order of Hymenochaetales and Fomitopsidaceae (LE-BIN 4109, LE-BIN 4115 Fomitopsis betulina), Irpicaceae (LE-BIN 3978, LE-BIN 4110 Gloeoporus dichrous), Meruliaceae (LE-BIN 4127 Phlebia rufa), Polyporaceae (LE-BIN 3578 Trametes gibbosa and LE-BIN 3995 Trametes pubescens), Sparassidaceae (LE-BIN 4114 Pycnoporellus fulgens) families from the Polyporales order.
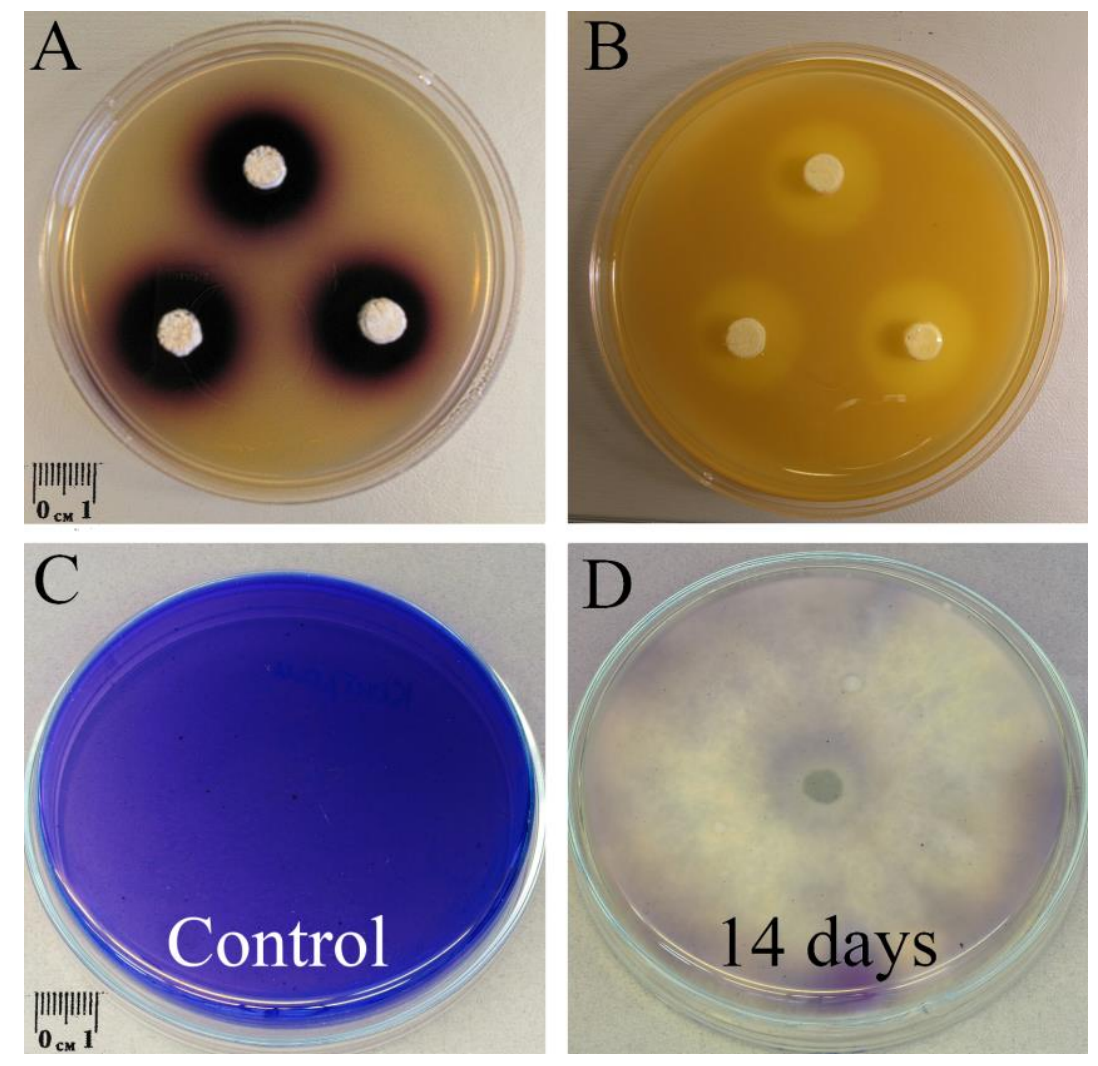

Fig. 2 - Dye decolorization and enzymatic activities of the strain LE-BIN 4119 Phlebia rufa: A oxidation activity (ABTS). B cellulolytic activity (CMC). C MEA medium with polyphenolic dye azure $\mathrm{B}(75 \mathrm{mg} / \mathrm{l})$. D dye decolorization inside the fungal colony. 
To summarize, qualitative analyses that are necessary to search for fungi with high biotechnological potential are effective and provide valuable information for further confirmation by quantitative methods of specific secreted enzymes. Moreover, qualitative assessment of enzymes allows us to perform screening of a large number of strains of fungi. The data obtained have expanded the range of fungal producers of enzymes of ligno- and cellulolytic complexes with high detoxification potential. The strains of LE-BIN 3969 Rhodofomes roseus, LE-BIN 4122 Trametes hirsuta and LE-BIN 4123 Trametes ochracea selected as a result of the rapid testing method are recommended for further study for biotechnology purposes.

\section{Acknowledgements}

The authors are grateful to Dr. Elena Sitnikova (deputy director of the "Bryanskiy les" State Biosphere Nature Reserve) for help with the organization of field work. This study was carried out within the framework of the institutional research project of the Komarov Botanical Institute ("Biodiversity, ecology, structural and functional features of fungi and fungus-like protists", AAAA-A19-119020890079-6).

\section{References}

Barrasa JM, Blanco MN, Esteve-Raventós F, Altés A et al. 2014 - Wood and humus decay strategies by white-rot basidiomycetes correlate with two different dye decolorization and enzyme secretion patterns on agar plates. Fungal Genetics and Biology 72, 106-114.

Costa S, Dedola DG, Pellizzari S, Blo R et al. 2017 - Lignin biodegradation in pulp-and-paper mill wastewater by selected white rot fungi. Water 9, 935-941.

Floudas D, Binder M, Riley R, Barry K et al. 2012 - The Paleozoic origin of enzymatic lignin decomposition reconstructed from 31 fungal genomes. Science 336(6089), 1715-1719.

Hernández-Luna CE, Gutiérrez-Soto G, Salcedo-Martínez SM. 2008 - Screening for decolorizing basidiomycetes in Mexico. World Journal of Microbiology and Biotechnology 24(4), 465473.

Klán J, Baudišová D. 1990 - Enzyme activity of mycelial cultures of saprotrophic macromycetes (Basidiomycotina). I. Methods of hydrolases estimation. Česká Mykologie 44(4), 203-211.

Klein OI, Stepanova EV, Koroleva OV, Kulikova NA. 2011 - Use of basidiomycetes in industrial waste processing and utilization technologies: fundamental and applied aspects (review). Applied Biochemistry and Microbiology 47(6), 565-579.

Manavalan T, Manavalan A, Heese K. 2014 - Characterization of lignocellulolytic enzymes from white-rot fungi. Current Microbiology 70(4), 485-498.

Pointing SB. 1999 - Qualitative methods for the determination of lignocellulolytic enzyme production by tropical fungi. Fungal Diversity 2, 15-31.

Psurtseva NV. 2018 - Collection strains of macromycetes - valuable bioresources with high pharmacological potential. Advances of medical mycology 19, 188-192.

Stalpers JA. 1978 - Identification of wood-inhabiting Aphyllophorales in pure culture. Studies in Mycology 16, 1-248.

Upadhyay P, Shrivastava R, Agrawal PK. 2016 - Bioprospecting and biotechnological applications of fungal laccase. 3 Biotech 6(1), 15-27.

Wong DW. 2009 - Structure and action mechanism of ligninolytic enzymes. Applied Biochemistry and Biotechnology 157(2), 174-209. 